\title{
Community Activities Through The Watershed Basin Batanghari Viewed From The Historical Perspective
}

\author{
(Case Study In Batanghari Regency)
}

\author{
Apdelmi \\ Faculty of Cultural Sciences \\ Universitas Jambi \\ Jambi, Indonesia
}

\author{
Hadiyanto \\ Faculty of Cultural Sciences \\ Universitas Jambi \\ Jambi, Indonesia
}

\begin{abstract}
The study's aim was comparing community activities along the Batanghari river in the past and present, knowing the economic, social and cultural activities of Batanghari people living along the river basin. The study was conducted from March to October 2017 using a single case study. The location of this research was along Batanghari River Basin in Batanghari Regency. The results showed that community activities along the river Batanghari are not as it used to be because it has experienced a shift or transfer function. In the Dutch colonial period Batanghari river had a very important role, namely as a means of public transportation by boat. In addition Batanghari river was also used by society as a means to transact or traditional markets at some point on the edge of the river Batanghari, but now the markets are not working anymore. Many buildings that are on the edge of the river Batanghari has already damaged by time. This is because the Batanghari river has begun shallow and cannot be passed by large ships. Besides, the progress of land and air transportation make Batanghari River began to be abandoned.
\end{abstract} basin

Keywords-Bataghari river, community activities, watershed

\section{INTRODUCTION}

Batanghari Regency, nicknamed 'Bumi Serentak Bak Regam' was formed on December 1, 1948, through the Regulation of the Government Commissioner of the Republic of Indonesia No 81 / Kom / U dated 30 November 1948. Batanghari is one of 11 regencies / cities located in Jambi Province. Batanghari name comes from the name of the river that flows in this regency is Batanghari River.

The Batanghari River area has a long history. Before the 19th century AD, the river became an important means of transport from and to the interior. The transportation of goods and people is done by river channel. It is proven from some archaeological site which shows the existence of ancient settlement concentration in some places by the river Batanghari [1]. There are four temple complexes along Batanghari Watershed (DAS), especially in Upper area: Muaro Jambi temple complex, Padang Roco temple complex,
Sawah Island temple complex, and Rawa Mangambe temple complex. This temple complex shows that the river became the center of community activity at that time.

Dutch military fortress built the former Kraton Jambi on the right side of the river Batanghari that became a residential place of the Chinese, while the left side of the river there is the Arab village [2]. Some boat docks are also found in the Batanghari watershed. This strengthens the evidence that the river became the main activity of society at that time, especially in terms of trade.

Batanghari Regency is one of the areas in the Batanghari watershed and becomes part of maritime history. The villages in Batanghari Regency are generally located along the river basin. The houses are built on pillars consisting of wooden or bamboo cubicles and palm leaves [3]. The centers of vital activities and community tools such as markets, puskesmas and administrative offices are still standing along the river.

Historical evidence such as rajo building is located in the town of Muara Bulian and found on the edge of the river Batanghari. It is said that this ladder or staircase is the place where the king's way when sailing. Dutch heritage fortress located on the edge of the river Batanghari, in the area of Muaro Tembesi becomes other evidence that strengthens that the river played an important role and became the center of community activity at that time. Even the symbol of Batanghari Regency was inspired from the Batanghari river that is blue Logo $\mathrm{Y}$ showing the flow of Batanghari and Batang tembesi rivers.

However, over time, community activities in the Batanghari river basin are increasingly reduced. In addition to natural factors that cause ups and downs, the development of advanced land routes, illegal exploitation of rivers causing activities along the river stream is now reduced and changed functions. Therefore, the writer wanted to study how the activities of people along the river Batanghari viewed from a historical perspective. 


\section{METHOD}

This study was conducted for approximately six months starting from March to August 2017. This study is a historical study that uses a single case study. The location of this research was along Batanghari River Basin (DAS) in Batanghari Regency. Stages passed in this study were

a. Heuristics (gathering or locating sources), historical sources can also be called relics of human life, and the results of human activities communicated (L. Gottschalk in [4]). In this study the data was obtained through interviews with community figures, traditional leaders, and communities living along the river Batanghari. In addition, sources can be obtained through literature studies like historical notes, relics, oral tradition that exist along the river basin Batanghari.

b. Source Criticism, source criticism is generally conducted against the first sources, this critique involves verifying the source of testing the truth or accuracy of the source obtained [5]. Based on the above opinion, it can be said that all sources or data that have been collected or obtained by researchers either through interviews, written sources, historical relics, and so forth cannot be immediately trusted. The temporary data that has been collected must be ascertained through the source criticism.

c. Interpretation, interpreting or giving meaning to historical facts or evidence, whether in the form of documents, historical records, relics, and interviews that have been done before must be tested for validity and data reactivity [6].

d. Historiography (Writing), after all the research data collected and confirmed the truth then researchers began to narrate in the form of research results.

\section{Result AND Discussion}

\section{A. Geographical Condition}

Batanghari Regency is the oldest district in Jambi Province. Batanghari District was established on December 1, 1948 and is in the middle of Jambi Province. Based on geographical location Batanghari Regency abuts:

a. Regency of Tanjung Jabung Barat in the north.

b. Regency of Sarolangun and South Sumatera Province in the south.

c. Regency of Muaro Jambi in the east.

d. Regency of Tebo in the west.

\section{B. Community Economic Activities Throughout the Batanghari River Flows of the Dutch Colonial Period and Now}

In the Dutch colonial era, the sub-district of Muara Tembesi was used as the center of commerce. Not only the surrounding community who visited Tembesi Market, but also people from Marosebo Sub-district Ulu, Mersam, Bathin XXIV, Muara Bulian and other areas. At that time residents who came from outside Tembesi still used traditional transportation through river routes such as, motor ketek, and boat.

Currently the river is no longer used as a trade route because the market has a lot of standing in every district. Advanced transportation facilities such as four-wheeled vehicles and two-wheels make transportation of the river began to be abandoned.

\section{Socio-Cultural Society Throughout the Batanghari River Flows Dutch and Dutch Colonial Times}

The river became an important part of society in the Dutch colonial era, not only as a trade route, the river also became the center of community activities. River at that time was still used by people for daily needs, even for cooking and drinking because of the state of the river was still very good. However, the river is now no longer used for daily needs because the river is considered unfit for consumption. This is due to the mining in the river that is in the upper river.

In addition to the daily needs of people who live along the river as the village Selat utilize the river to cross to the island that is across the river batanghari, and there the community farm and raise livestock. Farm animals are mostly cattle.

In the Dutch colonial era, people along the river basin built a house on a large stage and had large glass windows in front of the house. They made the stage because it was located on the river Batanghari which if there was a flood, the house would not be submerged. And the materials used to build the house was a typical wood Tembesi wood and Bulian.

Community activity along the Batanghari river is not as it used to be. It has undergone a shift or transfer function of river Batanghari. Once in the Dutch colonial period Batanghari river has a very important role, namely as a means of public transportation through that time using the ship. In addition, Batanghari river is also used by society as a means to transact or traditional markets at some point on the edge of the river Batanghari. However the markets are not working anymore nowadays. Many of the buildings on the edge of the river Batanghari have been damaged by time, but it was once very important role for community activities. This is because the Batanghari River had begun to be shallow and cannot be passed by large ships as in the colonial period and also with the progress of land and air transportation, so that the Batanghari River has slowly started in leave or over function.

\section{CONCLUSION}

Community activities along the river Batanghari are not as it used to be because it has experienced a shift or transfer function. In the Dutch colonial period Batanghari river had a very important role, namely as a means of public transportation by boat. In addition Batanghari river was also used by society as a means to transact or traditional markets at some point on the edge of the river Batanghari, but now the markets are not working anymore.

\section{REFERENCES}

[1] A. Tasman, Menelusuri Jejak Kejayaan Melayu Jambi dan Perkembangannya. Jambi. Referensi, 2016. 
[2] N.J. Lindayanti, U. Hariadi, Menyibak Sejarah Tanah Pilih Pusako Betuah, Jambi, Badan Perpustakaan, Arsip dan Dokumentasi Kota Jambi, 2014

[3] J.L. Noor, Hariadi, Jambi 1500-1942, Jambi, Pusat Kajian Pengembangan Sejarah dan Budaya Jambi, 2013

[4] W. Pranoto, Suhartono, Teori dan Metodologi Sejarah, Yogyakarta. Graha Ilmu, 2010.

[5] H. Sjamsuddin, Metodologi Sejarah, Yogyakarta, Ombak, 2012

[6] A. Daliman, Metode Penelitian Sejarah, Yogyakarta, Ombak, 2015 